\title{
The Satisfaction Level of Undergraduate Medical and Nursing Students Regarding Distant Preclinical and Clinical Teaching Amidst COVID-19 Across India
}

This article was published in the following Dove Press journal:

Advances in Medical Education and Practice

\section{Siddhartha Dutta (D) \\ Sneha Ambwani \\ Hina Lal \\ Kishna Ram \\ Govind Mishra \\ Tarun Kumar \\ Shoban Babu Varthya}

Department of Pharmacology, All India Institute of Medical Sciences, Jodhpur,

Rajasthan, India
Correspondence: Tarun Kumar Department of Pharmacology, All India Institute of Medical Sciences, Room No. C-280, Second Floor, Medical College Building, Jodhpur, Rajasthan, 352005, India Tel +918447875716

Email tarunkmr759@gmail.com
Background: The COVID-19 pandemic has disrupted the educational system and led to a drastic shift of professional undergraduate teaching for medical and nursing students into online mode.

Methods: This was a cross-sectional, observational questionnaire-based study to assess the satisfaction level of the students. The questionnaire had 25 items of which 23 were questions with responses on the Likert scale and two items on views and suggestions were open-ended. The online questionnaire was shared through various messaging/mailing platforms. Overall satisfaction was assessed, and a satisfaction index was calculated for each item. Data are presented in frequencies and percentages, and SPSS was used to analyze the data.

Results: A total of 1068 students participated in the study. The majority were from the age group 21-23 years (54\%) and there was almost the same number of participants from both genders. The majority of the students were medical undergraduates $(n=919)$, were in their second year $(n=669)$, belonged to a government institution $(n=897)$ and used a mobile phone for their online classes $(n=871)$. The majority of the students were dissatisfied $(42 \%)$ with no significant difference between medical and nursing students $(p$ $=0.192)$. First-year students were significantly dissatisfied compared with other senior students $(\mathrm{p}=0.005)$. The maximum satisfaction index $(78.23 \%)$ was observed with faculties being supportive and responsive in resolving the queries and the minimum $(46.39 \%)$ was observed with issues related to communication and discussion with peer students. There were 662 responses as views which mostly contained negative comments regarding interaction and focus, practical learning, teaching content, and technological/infrastructural flaws. There was major dissatisfaction regarding the practical and clinical learning.

Conclusion: Online learning is essential at current times but is not an effective alternative for medical and nursing education. Face-to-face classes and practical sessions along with online learning can be a viable option.

Keywords: COVID-19, online teaching, satisfaction, satisfaction index, students

\section{Introduction}

The Coronavirus Disease 2019 (COVID-19) had brought the world to a standstill. In order to contain the spread of the virus, governments ensured lockdown which also included the closure of education institutions. ${ }^{1}$ With the unavailability of definitive treatment and uncertainty for the end of the pandemic, preventive measures are crucial in saving oneself from getting infected from this virus. The 
traditional way of classroom teaching was impossible as it would violate social distancing norms and would risk teachers and the students. ${ }^{2}$ This had a serious negative impact on the education system. Therefore, to continue with their professional curriculum, online teaching was the only option left to teach undergraduate medical and nursing students.

Distance learning is not a new model of learning but has its roots as correspondence (postal delivery) learning since the 18th century. ${ }^{3,4}$ Online/e-learning has been an optional and valuable tool for a long period but with the advances in technology and easier ways to interact with telecommunication, the education system has changed drastically and there was an immense rise in online learning via various digital platforms which has proved that distance learning is a viable option at present times. ${ }^{5-7}$ Online learning has its advantages over conventional teaching methods such as availability to a wider population especially in difficult areas where face-to-face teaching is not feasible, time-efficiency, flexibility to students, convenience, and easy accessibility. ${ }^{8}$ However, lack of motivation, absence of physical interaction with the instructor, social isolation, and no immediate feedback from the teacher are major disadvantages. ${ }^{6,8}$ In view of the pandemic situation, online teaching is justifiable but its usefulness in teaching medical and nursing courses is questionable as assessing student satisfaction with webbased learning systems has been a critical issue for researchers and academia. ${ }^{9-14}$ The literature shows varied results regarding the satisfaction of students with online or web-based learning. ${ }^{10,11}$ A few studies reported insecurities among the students and dropouts from the courses with online learning. Apart from this, other problems faced by the students were technical problems, internet issues, poor audio-visual transmission, etc. ${ }^{8,10,12}$ In professional courses such as medicine and nursing, hands-on practical learning, clinical postings, and patient interactions later in the curriculum play a crucial role in gaining skills. But the present condition does not warrant conventional face-to-face lectures, practical classes, or clinical postings for the students as it can unnecessarily expose them to the novel coronavirus unknowingly. Presently, due to COVID-19, we do not have many options for teaching the students and hence online interactive teaching is the best option we have in the current scenario. In view of such a scenario, this study was designed with an aim to assess the satisfaction level of undergraduate medical and nursing students and analyze the associated problems faced by the students during online teaching.

\section{Methods}

The present study was a prospective, cross-sectional, observational study conducted on the undergraduate medical and nursing students who were receiving online teaching for their professional course due to the lockdown imposed in view of the current pandemic of COVID-19 across India. The study was conducted during the period of 09/09/2020 to 28/09/2020. The study was conducted using a semi-structured questionnaire that was developed and adapted from the previous few studies. ${ }^{5,13,14}$ It was validated to assess logical consistencies, clarity, comprehensibility, the chronology of items, and refined accordingly to facilitate better comprehension and organization of the questionnaire. The questionnaire section 1 contained sociodemographic details and section 2 had the satisfaction questionnaires regarding online classes. There was a total of 25 questions and 23 of them were questions associated with their satisfaction with online classes, each of which was scored 1-5 on a five-point Likert scale $(5=$ Strongly agree, 4 = Agree, $3=$ Neutral, $2=$ Disagree, and 1 $=$ Strongly disagree). However, three out of 23 items (numbers 7,8 , and 12) were negative statements, and where scoring was done in a reverse manner $(5=$ Strongly disagree, $4=$ disagree, $3=$ Neutral, 2 = Agree, and $1=$ Strongly agree). Two questions on views and suggestions were open-ended. The Satisfaction Index (SI) of each item of the questionnaire was calculated using the following formula: ${ }^{15}$

S.I. $=\frac{[(\mathrm{n} 1 \times 1)+(\mathrm{n} 2 \times 2)+(\mathrm{n} 4 \times 4)+(\mathrm{n} 5 \times 5)]}{(\mathrm{n} 1+\mathrm{n} 2+\mathrm{n} 4+\mathrm{n} 5) 5} \times 100$

Where $n 1=$ Number of participants opted for Strongly disagree

$\mathrm{n} 2=$ Number of participants opted for Disagree

n4 $=$ Number of participants opted for Agree

n5 $=$ Number of participants opted for Strongly agree.

The questionnaire was administered through online mode by preparing google questionnaire forms and the link of the questionnaire was shared and distributed via various online platforms such as emails and messaging applications to various medical and nursing undergraduate students across various states of India. Online informed consent was taken from the participants at the beginning of the study and it was designed in such a way that only those giving consent could proceed to the study and answer the questionnaire. The data collection was done on the electronic platform. The names and identification of the 
students were not collected to protect the confidentiality and anonymity of participants.

\section{Ethics Statement}

The study was approved by the Institutional ethics committee, All India Institute of Medical Sciences, Jodhpur, India with certificate number AIIMS/IEC/2020-21/3100.

\section{Statistical Analysis}

The data were recorded into Microsoft Excel v.365 and analysis was performed using SPSS software (Statistical Package for the Social Sciences version 25, $\mathrm{IBM}^{\circledR}$ ). Continuous variables were presented as mean and standard deviation (SD) or median and interquartile range (IQR) based on the distribution. Categorical variables were presented as frequency and proportions. The satisfaction rate among medical and nursing graduates and their year of graduation were analyzed using the Chi-square test and a Kruskal-Wallis test with Bonferroni correction.

\section{Results}

\section{Sociodemographic Characteristics of the Students}

A total of 1137 students participated in the study and 69 of them disagreed for consent and were excluded. Finally, 1068 (94\%) participants were included in the study. The majority of the students were in the age group 21-23 years (54\%). The gender of the participants was equally matched. The majority of the students were medical students (86.4\%) and were studying in their second professional year (63\%). Most of them were from a government institution (84.5\%). The commonest device used for online teaching was a mobile $(82 \%)$ followed by laptops $(11.8 \%)$. The details of the sociodemographic profile are summarized in Table 1.

\section{Perception of Students Towards Online Teaching}

The majority of the students felt that with online teaching the goals and objectives were met, the content was communicated properly, the time was appropriately used, the quality of the content was comparable to conventional teaching, the faculties were supportive, responsive, and quick enough in resolving the queries, the faculties made the learning active by motivating and encouraging them to participate in discussions, gain knowledge regarding technology and being technically sound (Mode $=4)$. The details of the responses are shown in Table 2 .
Table I Summary of Sociodemographic Profile of Students

\begin{tabular}{|c|c|c|}
\hline \multicolumn{2}{|c|}{ Sociodemographic Characteristics } & \multirow{2}{*}{$\begin{array}{l}\begin{array}{l}\text { Number of } \\
\text { Participants (\%) }\end{array} \\
457(43 \%) \\
573(54 \%) \\
33(3 \%)\end{array}$} \\
\hline Age, $(n=1063)$ & $\begin{array}{l}18-20 \text { Years } \\
21-23 \text { Years } \\
24-28 \text { Years }\end{array}$ & \\
\hline Gender, $(n=1063)$ & $\begin{array}{l}\text { Male } \\
\text { Female }\end{array}$ & $\begin{array}{l}529(49.8 \%) \\
534(50.2 \%)\end{array}$ \\
\hline $\begin{array}{l}\text { Professional course, } \\
(n=1064)\end{array}$ & $\begin{array}{l}\text { Medical student } \\
\text { Nursing student }\end{array}$ & $\begin{array}{l}919(86.4 \%) \\
145(13.6 \%)\end{array}$ \\
\hline Year of course, $(n=1062)$ & $\begin{array}{l}\text { First year } \\
\text { Second year } \\
\text { Third year } \\
\text { Fourth year }\end{array}$ & $\begin{array}{l}65(6.1 \%) \\
669(63 \%) \\
214(20.2 \%) \\
114(10.7 \%)\end{array}$ \\
\hline Institution, $(n=106 \mid)$ & $\begin{array}{l}\text { Government } \\
\text { Private }\end{array}$ & $\begin{array}{l}897(84.5 \%) \\
164(15.5 \%)\end{array}$ \\
\hline $\begin{array}{l}\text { Type of electronic } \\
\text { device, }(n=1063)\end{array}$ & $\begin{array}{l}\text { Mobile phone } \\
\text { Laptop } \\
\text { Tablet } \\
\text { Desktop }\end{array}$ & $\begin{array}{l}87 \mid(82 \%) \\
125(\mid 1.8 \%) \\
53(5 \%) \\
14(1.3 \%)\end{array}$ \\
\hline
\end{tabular}

Abbreviation: $\mathrm{n}$, number of total participants.

\section{Overall Satisfaction Rate}

Satisfaction rate was determined by the number of participants with positive or negative responses/Total number of responses multiplied by 100 . A total of $392(37.76 \%)$ participants gave positive responses (Very satisfied and Satisfied) out of which 336 were medical and 56 were nursing graduates. A total of $435(42 \%)$ participants gave a negative response (Very dissatisfied and Dissatisfied) to online learning; out of these 386 were medical and 49 were nursing undergraduates. A Chi-square test of independence was applied to analyze the difference between medical and nursing undergraduates which was found to be non-significant $\left(X^{2}=1.69, \mathrm{p}=0.192\right)$. The overall satisfaction of first, second, third, and fourth-year medical and nursing undergraduates was compared. A Kruskal-Wallis test provided evidence of a significant difference (Kruskal-Wallis, $\mathrm{H}=10.10$, $\mathrm{df}=3$, $p=0.018$ ) between the various years of students. The overall dissatisfaction in the first-year students was almost double that of satisfaction ( $46.8 \%$ vs $23.4 \%$ respectively). Only third-year students among all the students had an overall satisfaction rate more than the dissatisfaction rate. On post $h o c$ analysis there was a significant difference between second-year and third-year students $(p=0.037$, adjusted using the Bonferroni correction). Although there 
Table 2 Perception of Medical and Nursing Undergraduate Regarding Online Learning

\begin{tabular}{|c|c|c|c|c|c|c|c|}
\hline Questions & SA, $n(\%)$ & $A, n(\%)$ & $\mathbf{N}, \mathbf{n}(\%)$ & $D, n(\%)$ & SD, $n(\%)$ & $\begin{array}{l}\text { MED, } \\
\text { IQR }\end{array}$ & Mode \\
\hline $\begin{array}{l}\text { I. With the online classes, I felt more comfortable in introducing myself to the faculty } \\
\text { as compared to conventional classroom teaching. }(n=1058)\end{array}$ & $73(6.9)$ & $219(20.7)$ & $264(25)$ & $298(28.2)$ & $204(19.3)$ & 3,2 & 2 \\
\hline $\begin{array}{l}\text { 2. While teaching online, the goal or objectives of each of the topics were met by the } \\
\text { faculty. }(n=1058)\end{array}$ & $80(7.6)$ & $378(35.7)$ & $256(24.2)$ & $211(19.9)$ & $133(12.6)$ & 3,2 & 4 \\
\hline 3. During online classes, the content of the class was communicated effectively. $(n=1057)$ & $76(7.2)$ & $324(30.7)$ & $255(24.1)$ & $264(25)$ & $138(13.1)$ & 3,2 & 4 \\
\hline 4. The faculty used class time for the online teaching well. $(n=1058)$ & $170(16.1)$ & $438(41.4)$ & $223(21.1)$ & $130(12.3)$ & $97(9.2)$ & 4,1 & 4 \\
\hline $\begin{array}{l}\text { 5. During online classes, the faculties were supportive and responsive in resolving my } \\
\text { queries. }(n=1059)\end{array}$ & $204(19.3)$ & $478(45.1)$ & $266(25.1)$ & $59(5.6)$ & $52(4.9)$ & 4,1 & 4 \\
\hline $\begin{array}{l}\text { 6. The response time from faculties was quick enough on asking any doubt during } \\
\text { online classes. }(n=1053)\end{array}$ & $189(17.9)$ & $423(40.2)$ & $292(27.7)$ & $88(8.4)$ & $61(5.8)$ & 4,1 & 4 \\
\hline 7. When learning online, I had difficulties in understanding the topics.* $(n=1057)$ & $286(27.1)$ & $313(29.6)$ & $213(20.2)$ & $199(18.8)$ & $46(4.4)$ & 2,2 & 2 \\
\hline 8. During online teaching, at times I often felt confused or lost. * $(n=1057)$ & $303(28.7)$ & $356(33.7)$ & $186(17.6)$ & $163(15.4)$ & $49(4.6)$ & 2,2 & 2 \\
\hline $\begin{array}{l}\text { 9. While teaching online, the faculty made learning an active process by motivating us, } \\
\text { helping to develop thought, encouraging us in participating in the discussion. }(n=1050)\end{array}$ & $107(10.2)$ & $340(32.4)$ & $306(29.1)$ & $177(16.9)$ & $120(11.4)$ & 3,2 & 4 \\
\hline $\begin{array}{l}\text { 10. This style of communication enabled me to get engaged with the faculty during } \\
\text { class discussions. }(n=1046)\end{array}$ & $77(7.4)$ & $281(26.9)$ & $296(28.3)$ & $257(24.6)$ & $135(12.9)$ & 3,2 & 3 \\
\hline $\begin{array}{l}\text { 11. The communication and discussion with other students were easier during online } \\
\text { classes. }(n=1048)\end{array}$ & $55(5.2)$ & $176(16.8)$ & $210(20)$ & $358(34.2)$ & $249(23.8)$ & 2,1 & 2 \\
\hline 12. I often had lingering questions about the content that were left unanswered. $*(n=1034)$ & $96(9.3)$ & $273(26.4)$ & $453(43.8)$ & $167(16.2)$ & $45(4.4)$ & 3,1 & 3 \\
\hline 13. With the online teaching, I felt more engaged with my studies. $(n=1047)$ & $82(7.8)$ & $207(19.8)$ & $213(20.3)$ & $291(27.8)$ & $254(24.3)$ & 2,2 & 2 \\
\hline $\begin{array}{l}\text { 14. During online classes, I felt I had more opportunities to interact with the faculty as } \\
\text { compared to conventional classroom teaching. }(n=1037)\end{array}$ & $78(7.5)$ & $230(22.2)$ & $206(19.9)$ & $303(29.2)$ & $220(21.2)$ & 2,2 & 2 \\
\hline $\begin{array}{l}\text { 15. With online teaching, I felt it is easy to ask questions to the faculty and clear my doubts } \\
\text { as compared to conventional classroom teaching. }(n=1039)\end{array}$ & $86(8.3)$ & $262(25.2)$ & $243(23.4)$ & $273(26.3)$ & $175(16.8)$ & 3,2 & 2 \\
\hline $\begin{array}{l}\text { 16. With the online teaching, I feel that it is easier to manage my studies as compared to } \\
\text { conventional classroom teaching. }(n=1035)\end{array}$ & $132(12.8)$ & $220(21.3)$ & $179(17.3)$ & $285(27.5)$ & $219(21.2)$ & 3,2 & 2 \\
\hline $\begin{array}{l}\text { 17. During online classes, the quality of the teaching material projected or taught were the } \\
\text { same or comparable to the one used during conventional classroom teaching. }(n=103 \mid)\end{array}$ & $134(13)$ & $383(37.1)$ & $221(21.4)$ & $177(17.2)$ & $116(11.3)$ & 4,2 & 4 \\
\hline $\begin{array}{l}\text { 18. An interactive online discussion along with a Power Point presentation is an } \\
\text { effective way of learning. }(n=1033)\end{array}$ & $117(11.3)$ & $375(36.3)$ & $202(19.6)$ & $198(19.2)$ & $14 \mid(13.6)$ & 3,2 & 4 \\
\hline 19. I prefer online teaching and feel online education is worth my time. $(n=1033)$ & $115(11.1)$ & $209(20.2)$ & $220(21.3)$ & $247(23.9)$ & $242(23.4)$ & 3,2 & 2 \\
\hline $\begin{array}{l}\text { 20. The faculties during online classes helped to build discussion and recognize } \\
\text { problem areas in my studies. }(n=1029)\end{array}$ & $77(7.5)$ & $292(28.4)$ & $333(32.4)$ & $200(19.4)$ & $127(12.3)$ & 3,2 & 3 \\
\hline $\begin{array}{l}\text { 21. I got constructive (positive and negative) feedback from the faculties on my } \\
\text { assignments. }(n=1029)\end{array}$ & $66(6.4)$ & $278(27)$ & $417(40.5)$ & $148(14.4)$ & $120(11.7)$ & 3,2 & 3 \\
\hline $\begin{array}{l}\text { 22. These online classes have helped me to gain knowledge regarding technology and } \\
\text { being technically sound. }(n=1036)\end{array}$ & $122(11.8)$ & $44 \mid(42.6)$ & $227(21.9)$ & $132(12.7)$ & $114(11)$ & 4,1 & 4 \\
\hline 23. Overall, how will you grade your experience with online teaching? $(n=1038)$ & $84(8.1)$ & $308(29.7)$ & $211(20.3)$ & $270(26)$ & 165 (15.9) & 3,2 & 2 \\
\hline
\end{tabular}

Note: *Negative questions.

Abbreviations: SA, strongly agree; A, agree; N, neutral; D, disagree; SD, strongly disagree; MED, median; IQR, interquartile range; mode. 
were differences in overall satisfaction and dissatisfaction among the various professional years of students, there was no evidence of a significant difference between first year vs the fourth year, first-year vs the second year, first-year vs the third year, fourth year vs the second year, fourth-year vs the third year $(\mathrm{p}=1.0, \mathrm{p}=1.0, \mathrm{p}=0.097, \mathrm{p}=1.0, \mathrm{p}=0.159$ respectively) (Figure 1).

\section{Satisfaction Index}

The maximum satisfaction index was seen with item number $5(78.23 \%)$ which was related to faculties being supportive and responsive in the resolution of queries and the minimum was observed with item number $11(46.39 \%)$ which was regarding communication and discussion with other peer students. The SI of various items is illustrated in Figure 2.

\section{Views and Suggestions of Students on Online Teaching}

The views or opinions of the participants regarding online teaching were broadly classified into six categories as follows: (a) Interaction and focus, (b) Learning outcome, (c) Teaching content, (d) Practical learning, (e) Technological aspect, and (f) Time management, which is further subclassified into positive and negative opinions. There was a total

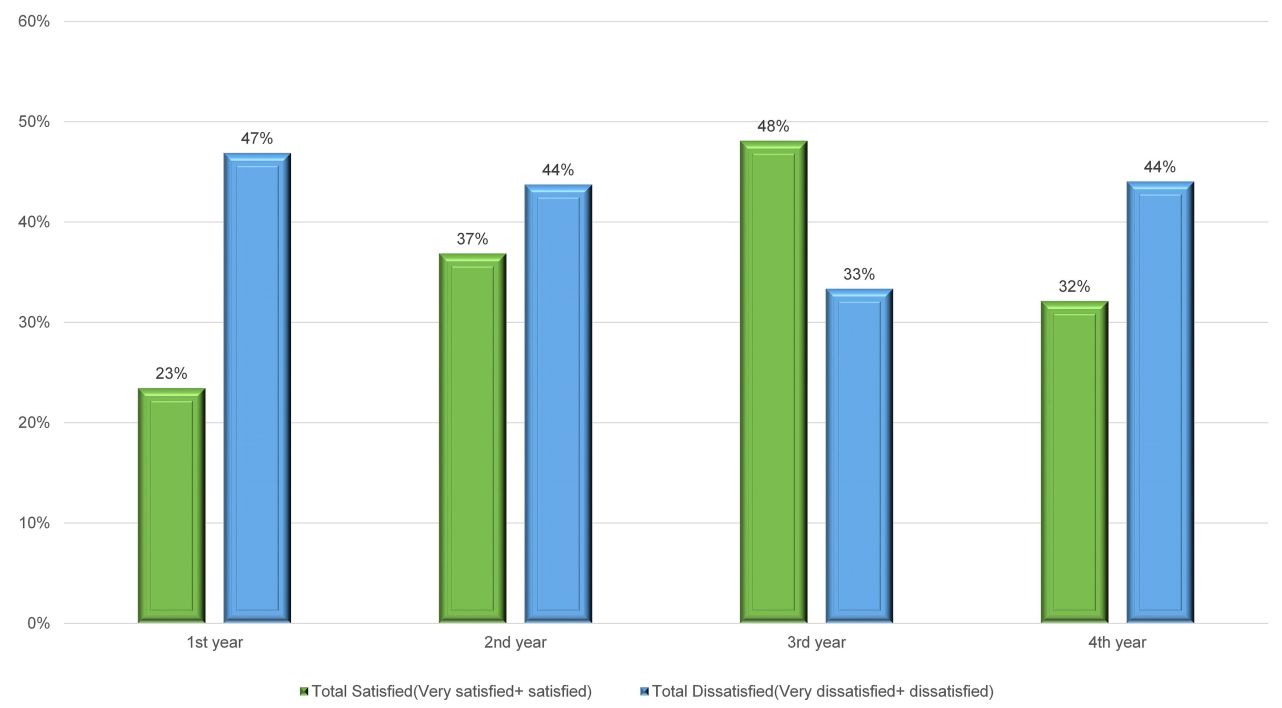

Figure I Comparison of overall satisfaction rate across various semesters.

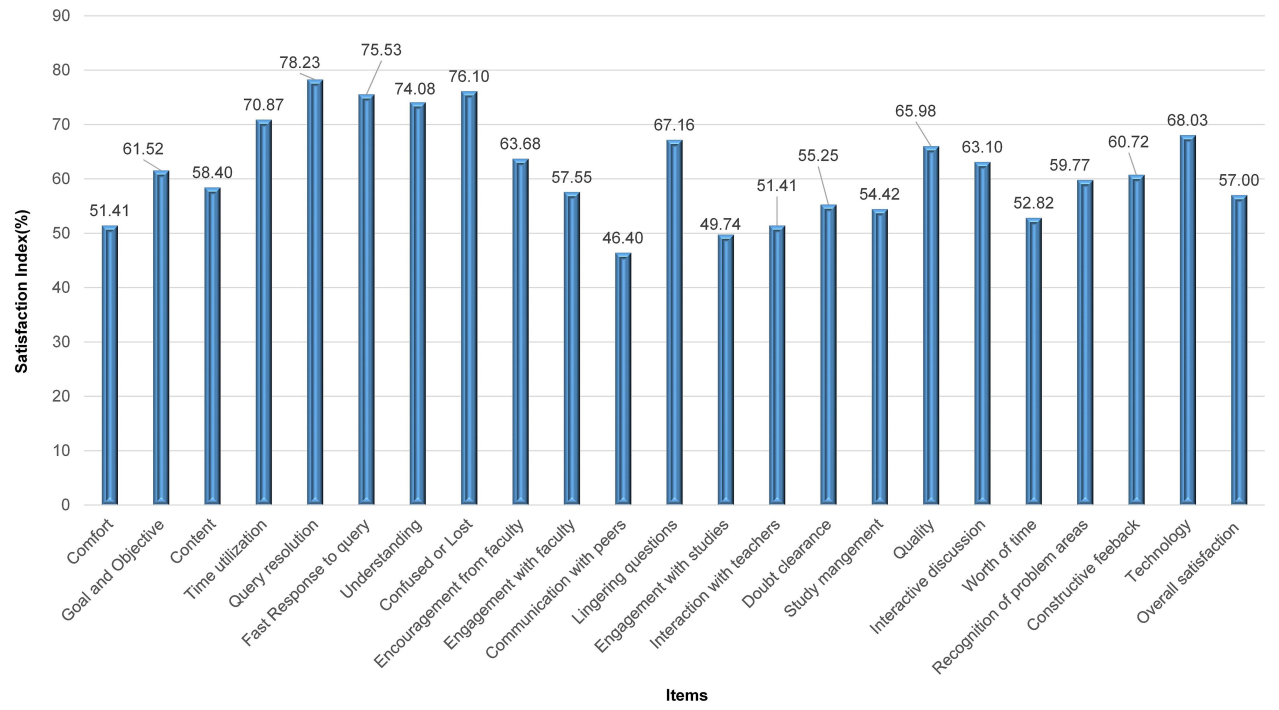

Figure 2 Satisfaction index of medical and nursing undergraduates regarding online teaching. 
of 662 responses as views/opinions of which 80 responses were excluded because they were unrelated or neutral. Finally, 582 responses were selected and subdivided into positive and negative responses. The majority of the responses in the categories "Interaction and focus", "Practical learning", "Teaching content", and "Technological aspect" were negative in nature. The most common views in each segment are shown in Table 3. Similarly, there were 505 responses as suggestions and the most common suggestions are summarized in Table 4.

\section{Discussion}

This study was conducted to assess the satisfaction of medical and nursing students with virtual classes after disruption of physical teaching due to the COVID 19 pandemic. Most of the students were medical students, second-year undergraduates, and from a government institution. By and large the students were dissatisfied, with maximum dissatisfaction among the first years with the online mode of teaching due to various reasons. They were generally satisfied with the support and response from the teaching faculties and dissatisfied with the communication/technology issues and lack of practical or clinical learning.

The International Association of Universities (IAU) COVID-19 Global Impact Survey observed that about 90\% of institutes observed major disruption or were completely closed during this pandemic and nearly two-thirds of institutes transformed their classroom teaching activities with virtual

Table 3 Summary of the Views or Opinions of Medical and Nursing Undergraduates Regarding Online Teaching

\begin{tabular}{|c|c|c|c|c|}
\hline \multirow{2}{*}{$\begin{array}{l}\text { Categories of } \\
\text { Opinion/Suggestions }\end{array}$} & \multicolumn{2}{|c|}{ Positive Comments } & \multicolumn{2}{|c|}{ Negative Comments } \\
\hline & $\mathbf{N}$ & Most Common Responses & $\mathbf{N}$ & Most Common Responses \\
\hline Interaction and Focus & 35 & $\begin{array}{l}\text { (a) Easy for introverts to interact with } \\
\text { faculty } \\
\text { (b) Good focus with less distraction } \\
\text { (c) More comfortable at home } \\
\text { (d) Can consult books simultaneously } \\
\text { (e) More flexibility }\end{array}$ & 53 & $\begin{array}{l}\text { (a) Disturbance, distraction with mobile and notifications } \\
\text { (b) No regular studies } \\
\text { (c) Lack of teaching environment at home } \\
\text { (d) Lack of face-to-face interaction with teachers }\end{array}$ \\
\hline Learning outcome & 145 & $\begin{array}{l}\text { (a) Good alternative in pandemic } \\
\text { (b) Can take screenshots easily } \\
\text { (c) Reliable } \\
\text { (d) Something is better than nothing }\end{array}$ & 128 & $\begin{array}{l}\text { (a) Not as good as conventional teaching } \\
\text { (b) Not a match for face-to-face lectures }\end{array}$ \\
\hline Teaching Content & 8 & (a) Regular assignment helped a lot & 68 & $\begin{array}{l}\text { (a) Not suitable for medical studies } \\
\text { (b) Students taking classes of other students as assignments } \\
\text { are not acceptable } \\
\text { (c) Only sharing PPT/PDF files without live classes is not } \\
\text { acceptable }\end{array}$ \\
\hline Practical learning & 0 & & 34 & $\begin{array}{l}\text { (a) Ist and 2nd year online classes are acceptable but not } \\
\text { for 3rd and 4th year } \\
\text { (b) No clinical postings } \\
\text { (c) No interaction with patients } \\
\text { (d) Anatomy dissection hard to understand on virtual } \\
\text { platform }\end{array}$ \\
\hline Technological Aspect & 5 & $\begin{array}{l}\text { (a) Online learning is effective and neces- } \\
\text { sary tool in today's scenario }\end{array}$ & 66 & $\begin{array}{l}\text { (a) No internet connection/Network issues } \\
\text { (b) Long screen time causes health-related problems such as } \\
\text { eye pain, headache, ear pain, etc. }\end{array}$ \\
\hline Time Management & 25 & $\begin{array}{l}\text { (a) Time saving } \\
\text { (b) More time for self-study } \\
\text { (c) Convenient }\end{array}$ & 15 & $\begin{array}{l}\text { (a) Not effective } \\
\text { (b) Waste of time }\end{array}$ \\
\hline
\end{tabular}

Abbreviations: N, number of responses; PPT, PowerPoint presentations; PDF, portable document format. 
Table 4 Summary of Suggestions Regarding Online Teaching

\begin{tabular}{|c|c|}
\hline $\begin{array}{l}\text { Categories of } \\
\text { Suggestions }\end{array}$ & Most Common Suggestions \\
\hline $\begin{array}{l}\text { Interaction and } \\
\text { focus }\end{array}$ & $\begin{array}{l}\text { (a) More interactive classes with revision } \\
\text { (b) More questions should be asked from students } \\
\text { (c) More time should be devoted to questions and } \\
\text { answers with discussion between students and } \\
\text { faculty } \\
\text { (d) Give break between two classes } \\
\text { (e) More discipline in online classes should be executed } \\
\text { (f) Enhance group participation }\end{array}$ \\
\hline Learning outcome & $\begin{array}{l}\text { (a) Video lectures should be recorded and sent online } \\
\text { (b) Should be continued for theory classes }\end{array}$ \\
\hline Teaching content & $\begin{array}{l}\text { (a) More interactive sessions rather than just sharing } \\
\text { PPT/PDF files } \\
\text { (b) More image based and animation-based learning } \\
\text { (c) More assignments, tests and MCQs along with } \\
\text { quizzes during class } \\
\text { (d) Send study material (PPT/PDF files) before lecture } \\
\text { (e) Teach at slow/steady pace } \\
\text { (f) Answer for assignment and test should be discussed } \\
\text { (g) Separate session for doubt clearing } \\
\text { (h) For theory classes, online mode is enough but for } \\
\text { practical classes physical presence is necessary }\end{array}$ \\
\hline Practical learning & $\begin{array}{l}\text { (a) Arrange practical classes } \\
\text { (b) Resume clinical postings } \\
\text { (c) Practical classes should always be physical } \\
\text { (d) Practical must be covered in online with demonstra- } \\
\text { tion and videos }\end{array}$ \\
\hline $\begin{array}{l}\text { Technological } \\
\text { aspect }\end{array}$ & $\begin{array}{l}\text { (a) Lot of internet data consumption and costly data } \\
\text { packages } \\
\text { (b) Network connectivity issue } \\
\text { (c) Use interactive apps such as Zoom meetings; Google } \\
\text { meet instead of just forwarding PPT/PDF files } \\
\text { (d) Lots of health problems are faced during constantly } \\
\text { watching the screen } \\
\text { (e) Notepads should be used to simulate classroom } \\
\text { teaching along with PDF file } \\
\text { (f) Lack of proper tools in students such as laptops and } \\
\text { computers }\end{array}$ \\
\hline Time management & (a) Properly schedule the classes with prior information \\
\hline
\end{tabular}

Abbreviations: PPT, PowerPoint presentations; PDF, portable document format; MCQ, multiple choice questions.

teaching via platforms such as e-Classrooms, Google meet, Zoom video communications, etc. ${ }^{16}$ Abrupt transitions of regular physical teaching, practical classes, and clinical postings to virtual teaching were to balance the students' professional learning with safety and prudent utilization of limited preventive resources like personal protection equipment, following norms of social distancing. Trelease et al. in their study observed that integration of virtual teaching is an essential reform for continuing medical education and can improve it to a great extent. ${ }^{17}$
In this study, we analyzed the students' satisfaction with online classes. Traditional face-to-face teaching is considered as a habitual pattern of routine learning particularly in professional courses such as medicine and nursing. Face-to-face sessions not only draw the attention of the learners but also anchor the focus by more interactions and brainstorming activities. In this study, the overall satisfaction levels of students were low (37.76\%), and the majority were dissatisfied (42\%); some students also complained of stress and health-related problems because of the unplanned transition towards virtual teaching. A study done by Singh et al. reported that students believed that the physical classes could be a better platform than virtual classes even if the virtual classes were well adapted. ${ }^{18}$

On a positive note, students were satisfied with the source and quality of information (SI $=66 \%$ ), individualized learning, control over the educational content, sequence of learning, and time management ( $\mathrm{SI}=71 \%$ ). However, students were largely dissatisfied with the cancellation of clinical rounds, ward posting, and real patient interaction which had deprived the students of gaining and enhancement of their clinical skills which is an essential part of the medical and nursing professional curriculum. Earlier studies have observed that interaction with virtual teaching during undergraduate medical training contributes to improved core competency, medical knowledge, and overall learning. ${ }^{19,20}$

The majority of the students were satisfied with the fact that the faculties were being supportive, responsive, and quick enough to resolve their queries $(\mathrm{SI}=75.53 \%)$. The study results were supported by a previous study done by Singh et al. ${ }^{18}$ The overall satisfaction rate of first-year undergraduates was comparatively very low (23\%) compared with senior undergraduate students i.e. second-, third-, and fourth-year students $(37 \%, 33 \%$, and $32 \%$ respectively). The probable explanation for this finding would be as first-year students are new to the curriculum, understanding new topics and comprehending the medical terminologies for the first time is a challenging task for them and could be the reason for overall dissatisfaction with the online mode of teaching. The senior students however can better comprehend the topics and therefore were relatively more satisfied compared with the first years. They also accepted the fact that at the time of the current pandemic, online classes were the best option to continue the teaching curriculum. Some students opined that online teaching is well suited for the theory classes but 
not for practical classes, clinical postings, and patientbased interactive learning. A systematic review and metaanalysis by Pei et al. found that test scores of learning outcomes between virtual and traditional teaching methods were comparable, which indicates that theoretical knowledge was not greatly affected but hands-on training may be compromised. $^{20}$ Practical learning has been highly compromised during this pandemic and junior undergraduates stated that basic medical science topics like anatomy dissection in virtual classes and online practice sessions were difficult for them to understand and comprehend( $N=34)$. Similarly, senior undergraduates stated the issues of being deprived of clinical skills and interactions with patients.

Student-faculty interaction plays a critical role in learning and a majority had interactive discussions (SI = $63 \%$ ). Interactive learning activities like problem-based learning and active discussions while teaching have been found to be effective and able to motivate and engage the students in enhancing learning outcomes. ${ }^{21}$ The biggest challenge is establishing an environment of interactive learning in an online or virtual teaching class because of various factors like inhibition among students, technological problems, etc. which was seen in this study.

However, study participants suggested that interactive and focused virtual classes can be further improved if the content of the lecture is animated or image-based along with a slow and steady pace of teaching, sharing of study material before a lecture, more assignments, tests, and multiple-choice questionnaires to assess the learning along with quizzes during class and a separate session for doubt clearance are conducted during the online classes.

Another challenge observed in this study was the technological aspect $(\mathrm{N}=66)$. Poor accessibility to the network, increasing cost due to costly data packages along with heavy dependence on mobile phones (82\%) for attending e-classes, were the most important limitations. These limitations were potential causes for lower satisfaction rates in students. The findings were supported by Chandrasinghe et al., who concluded that the lack of reliable network infrastructure was a major constraint in online teaching. ${ }^{22}$ Poor accessibility to hardware and overwhelming dependence on mobile phones, which have a smaller screen size, might be a crucial reason for the health-related problems such as eye pain, headache, ear pain, etc. as stated by the students.

Active support from the institution is crucial for the attainment of success in virtual learning. A rapid transition from physical to virtual classes without addressing various shortcomings related to technology/infrastructure barriers, teacher training, and student learning might result in less satisfactory outcomes. Implementation of virtual or e-learning in medical education is a strenuous task especially in low-middle-income countries like India because infrastructure and technological issues affect the transition from lecture-based teaching to self-directed online learning. ${ }^{2,23}$ Despite tremendous efforts being put on to deliver effective learning, it is expected that integration of a few components of traditional teaching with virtual classes like the Socratic method of teaching can improve the student's satisfaction. These shortcomings can be addressed by an integrated approach, which includes improving accessibility, network infrastructure and key skill development programs for faculties. Some of the promising teaching techniques like the blended learning method, and student engagement using the MultipleAttempt Quizzes method (SMAQ) address the shortcomings of virtual teaching. ${ }^{24}$ In the blended learning method, the learning is integrated web-based teaching with a small group, providing online educational materials along with interactive classroom lectures and hands-on practical classes. $^{25,26}$ Shaffer et al. observed that the blended learning method was effective in training students in radiological anatomy. ${ }^{25}$ A study by Hughes et al. observed that the SMAQ method was effective in nursing student engagement using weekly participation tasks. ${ }^{27}$ In support of this a study done by Guy et al. concluded that online simulations or virtual classes seem to be most effective when they are used complementary to conventional lectures which support better effective learning. ${ }^{9}$

\section{Strengths}

The present study is one of the first comprehensive crosssectional studies to assess the satisfaction index of virtual classes amidst the COVID-19 pandemic in India, which includes students of medical and nursing colleges across India ensuring the large diversity of the sample.

\section{Limitations}

As the study participants were from a medical and nursing background, this study's findings may not be generalized to students of other disciplines.

\section{Conclusion and Implications}

Virtual online teaching is an essential alternative in a situation like COVID-19 and it must have 
a complementary role in the training of medical and nursing students. This study highlights the issues crucial in online teaching and helps in the understanding of the essential changes to be made in order to overcome the obstacles in teaching the professional medical and nursing curriculum virtually. Curricular innovation and transformation such as the development of supplementary e-resources for medical and nursing graduates will enable them to focus more on clinical or practical classes and can improve the effectiveness of the online classes, hence improving satisfaction levels among students.

\section{Acknowledgment}

We would like to acknowledge the medical and nursing students across India who participated in the study and faculty members who helped in the completion of this study.

\section{Author Contributions}

All authors made a significant contribution to the work reported, whether that is in the conception, study design, execution, acquisition of data, analysis, and interpretation, or in all these areas; took part in drafting, revising, or critically reviewing the article; gave final approval of the version to be published; have agreed on the journal to which the article has been submitted, and agree to be accountable for all aspects of the work.

\section{Funding}

There is no funding to report.

\section{Disclosure}

The authors report no conflicts of interest for this work.

\section{References}

1. World Health Organization. Coronavirus disease (COVID-19)-events as they happen. Available from: https://www.who.int/emergencies/dis eases/novel-coronavirus-2019/events-as-they-happen. Accessed October 18, 2020.

2. Policy brief: education during COVID-19 and beyond. Available from: https://www.un.org/development/desa/dspd/wp-content/uploads/sites/ 22/2020/08/sg_policy_brief_covid-19_and_education_august_2020. pdf. Accessed October 18, 2020.

3. Kentnor HE. Distance education and the evolution of online learning in the United States. Curriculum and Teaching Dialogue. 2015;17 (1):21-34.

4. Pant A. Distance learning: history, problems and solutions. $A d v$ Comput Sci Inf Technol. 2014;1(2):6.

5. Walker SL, Fraser BJ. Development and validation of an instrument for assessing distance education learning environments in higher education: the distance education learning environments survey (DELES). Learn Environ Res. 2005;8(3):289-308. doi:10.1007/s10984-0051568-3
6. Tabatabai S. COVID-19 impact and virtual medical education. $J A d v$ Med Educ Prof. 2020;8(3):140-143. doi:10.30476/ jamp.2020.86070.1213

7. Alkhowailed MS, Rasheed Z, Shariq A, et al. Digitalization plan in medical education during COVID-19 lockdown. Inform Med Unlocked. 2020;20:100432. doi:10.1016/j.imu.2020.100432

8. Panchabakesan S. Problems and prospectives in distance education in india in the 21st century. Probl Educ. 2011;30:113-122.

9. Guy RS, Lownes-Jackson M. The use of computer simulation to compare student performance in traditional versus distance learning environments. IISIT. 2015;12:95-109. doi:10.28945/2254

10. Sweet R. Student dropout in distance education: an application of Tinto's model. Distance Educ. 1986;7(2):201-213. doi:10.1080/ 0158791860070204

11. Chiu C-M, Hsu M-H, Sun S-Y, Lin T-C, Sun P-C. Usability, quality, value and e-learning continuance decisions. Comput Educ. 2005;45 (4):399-416. doi:10.1016/j.compedu.2004.06.001

12. Knapper CK. Lifelong learning and distance education. $\mathrm{Am}$ J Distance Educ. 1988;2(1):63-72. doi:10.1080/08923648809526609

13. Strong R, Irby TL, Wynn JT, McClure MM. Investigating students' satisfaction with elearning courses: the effect of learning environment and social presence. J Agric Educ. 2012;53(3):98-110. doi:10.5032/ jae.2012.03098

14. Roach V, Lemasters L. Satisfaction with online learning: a comparative descriptive study. J Interact Online Learn. 2006;5 (3):317-332.

15. Guilbert JJ. Educational handbook for health personnel. World Health Organization; 1998. Available from: https://apps.who.int/iris/handle/ 10665/42118. Accessed October 22, 2020.

16. Marinoni G, Van't Land H, Jensen T. The impact of Covid-19 on higher education around the world. IAU Global Survey Report. 2020. Available from: https://www.iau-aiu.net/IMG/pdf/iau covid19 and he_survey_report_final_may_2020.pdf. Accessed October 22, 2020.

17. Trelease RB. From chalkboard, slides, and paper to e-learning: how computing technologies have transformed anatomical sciences education. Anat Sci Educ. 2016;9(6):583-602.

18. Singh K, Srivastav S, Bhardwaj A, Dixit A, Misra S. Medical education during the COVID-19 pandemic: a single institution experience. Indian Pediatr. 2020;57(7):678-679. doi:10.1007/ s13312-020-1899-2

19. Guze PA. Using technology to meet the challenges of medical education. Trans Am Clin Climatol Assoc. 2015;126:260-270.

20. Pei L, Wu H. Does online learning work better than offline learning in undergraduate medical education? A systematic review and meta-analysis. Med Educ Online. 2019;24(1):1666538. doi:10.1080/ 10872981.2019.1666538

21. Redmond CE, Healy GM, Fleming H, McCann JW, Moran DE, Heffernan EJ. The integration of active learning teaching strategies into a radiology rotation for medical students improves radiological interpretation skills and attitudes toward radiology. Curr Probl Diagn Radiol. 2020;49(6):386-391. doi:10.1067/j.cpradiol.2019.07.007

22. Chandrasinghe PC, Siriwardana RC, Kumarage SK, et al. A novel structure for online surgical undergraduate teaching during the COVID-19 pandemic. BMC Med Educ. 2020;20(1):1-7. doi:10.1186/s12909-020-02236-9

23. Potomkova J, Mihal V, Cihalik C. Web-based instruction and its impact on the learning activity of medical students: a review. Biomed Pap Med Fac Univ Palacky Olomouc Czechoslov. 2006;150 (2):357-361. doi:10.5507/bp.2006.055

24. Watson J Blending learning: the convergence of online and face-toface education. Available from: https://files.eric.ed.gov/fulltext/ ED509636.pdf. Accessed October 24, 2020.

25. Shaffer K, Small JE. Blended learning in medical education: use of an integrated approach with web-based small group modules and didactic instruction for teaching radiologic anatomy. Acad Radiol. 2004;11(9):1059-1070. doi:10.1016/j.acra.2004.05.018 
26. Venkatesh S, Rao YK, Nagaraja H, Woolley T, Alele FO, MalauAduli BS. Factors influencing medical students' experiences and satisfaction with blended integrated E-learning. Med Princ Pract. 2020;29(4):396-402. doi:10.1159/000505210
27. Hughes M, Salamonson Y, Metcalfe L. Student engagement using multiple-attempt "Weekly Participation Task" quizzes with undergraduate nursing students. Nurse Educ Pract. 2020;46:102803. doi:10.1016/j.nepr.2020.102803

\section{Publish your work in this journal}

Advances in Medical Education and Practice is an international, peerreviewed, open access journal that aims to present and publish research on Medical Education covering medical, dental, nursing and allied health care professional education. The journal covers undergraduate education, postgraduate training and continuing medical education including emerging trends and innovative models linking education, research, and health care services. The manuscript management system is completely online and includes a very quick and fair peer-review system. Visit http://www.dovepress.com/testimonials.php to read real quotes from published authors. 